\title{
Investigation of muck drawing in blocks with trapezoid sills
}

\author{
Mykola Stupnik ${ }^{1 *}$, and Olena Kalinichenko ${ }^{1}$ \\ ${ }^{1}$ Kryvyi Rih National University, Department of Underground Mining of Mineral Deposit, \\ 11 Matusevycha Ave., 50027 Kryvyi Rih, Ukraine
}

\begin{abstract}
The article is aimed at determining regularities of muck drawing in blocks and developing the technology of enhancing of muck ore parameters through shaping a trapezoid block sill. To confirm the suggested assumptions, study regularities of forming and determine contours of crests after full muck drawing from the second stage blocks, laboratory experiments have been conducted on drawing muck ore on the boundary with solidifying backfill massif of I stage stopes. For the first time there have been determined numerical dependencies of ore losses in crests on the contact with the solidifying backfill massif of the I stage stopes after ore drawing from the II stage blocks on the dead stope height and dips of side surfaces of trapezoid basis of sill pillars when forming the trapezoid sill with inclined side surfaces of the lower part of the I stage stopes. There are developed methods of calculating ore losses in crests on the contact with the solidifying backfill massif of I stage stopes after muck drawing from the II stage blocks. There are proposed methods of determining optimal parameters of mining ore deposits considering minimization of re losses in crests and increase of muck extraction from II stage blocks.
\end{abstract}

\section{Introduction}

Muck can be drawn in the contact with the muck ore waste rocks, on the contact with the solid ores or on the contact with the solidifying massif of artificial backfill. The character and regularities of drawing muck from a stope depending on characteristics of the contact. Considering these regularities, muck drawing on the contact with the solidifying artificial massif in mining the block with caving ore and enclosing rocks is similar to drawing ore on the contact with the solid ore massif $[1-7,11]$.

When drawing muck on the contact with the solid ore or solidifying artificial massif, muck loss in crests between drawpoints and on the contact with the solid massif becomes the main disadvantage.it should be noted that, according to G.M. Malakhov [1], muck losses in crests between drawpoints remain present regardless the drawn ore layer height.

According to investigations conducted, relative losses depend on the height of the layer of the drawn ore, its physical and mechanical characteristics and parameters of the drawing ellipsoid and the block geometry [8].

\footnotetext{
* Corresponding author: mstupnik2012@gmail.com
} 
Currently, in Kryvbas when mining deposits with caving ores and enclosing rocks, ore losses in blocks reach $15-17 \%$ and sometimes more, including ore losses in crests accounting for up to $7-12 \%$ of general ore losses in blocks.

Analysis of the character of ore loss formation in crests on the contact with the solid massif after full caved drawing from the II stage blocks enables the figure of the muck crests that remain in the block as losses, Fig. 1.

To enhance indices of muck ore extraction from blocks, the authors propose the technology of mining and backfilling an area of the ore body enabling reduction of ore losses in crests to $4-8 \%$.

The technology consists in the following.

First, I stage stopes are mined with forming the side surface of the lower part of the stope inclined towards II stage blocks (Fig. 2). The dip of the I stage stope lower part side surface is adequate to that of a drawing cone generatix of II stage blocks. In this case, from stopes of I stage blocks ore is drawn completely including the joined volume of the stope lower part (Fig. 2).

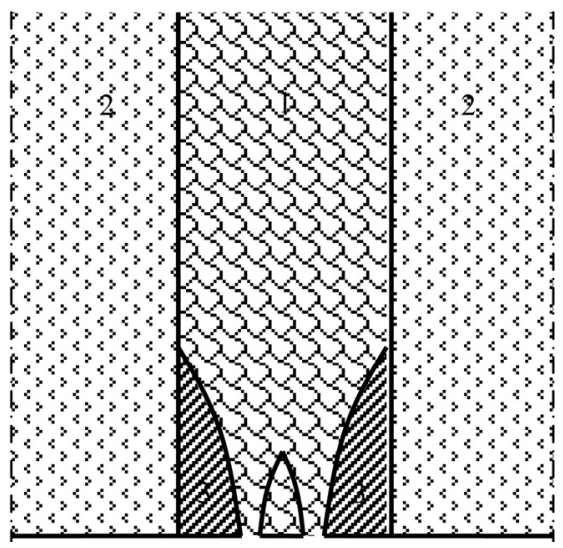

Fig. 1. Formation of ore losses in crests at the vertical contact of the drawn ore with the solidifying backfill massif of I stage stopes after full caved ore drawing from II stage blocks: 1 waste rocks, 2 - solidifying backfill of I stage stopes, 3 - ore losses in crests on the contact with I stage stope backfill.

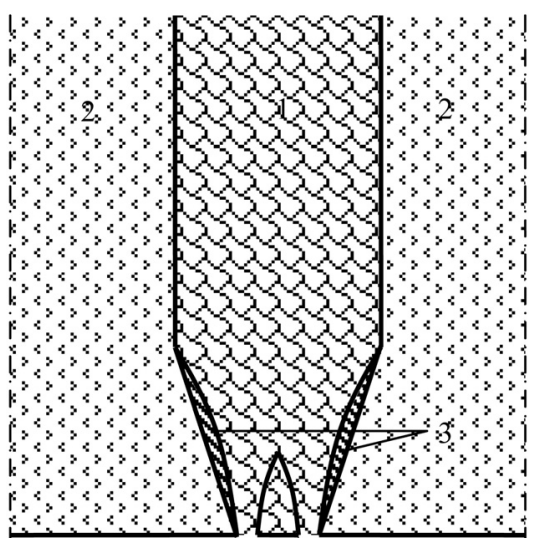

Fig. 2. Formation of ore losses in crests at the inclined contact of the drawn ore with the solidifying backfill massif of I stage stopes after full caved ore drawing from II stage blocks: 1 waste rocks, 2 - solidifying backfill of I stage stopes, 3 - ore losses in crests on the contact with I stage stope backfill.

Then, a I stage stope is filled with the solidifying backfill. After the backfill is strengthened, ore and enclosing rocks of II stage blocks are caved.

Ore drawing under overlying rocks id performed according to the theory of muck drawing from volumes in the form of ellipsoid of revolution.

The proposed formation of the sill of a block with inclined side surfaces in the lower part of I stage stopes allows elimination of ore losses in crests on the contacts with solidifying backfill massif of I stage stopes after complete caved ore drawing from II stage blocks.

\section{Methods}

Laboratory experiments on caved ore drawing on the boundary with the solidifying backfill massif of I stage stopes were conducted to confirm the suggested assumptions, investigate regularities of formation and determine crest contours after complete caved ore drawing from II stage blocks. 
The laboratory experiments were conducted at the ore drawing laboratory of the Department of underground mineral deposit mining, Kryvyi Rih National University, on standard static models of drawing for various mining and geological characteristics of rich iron ore deposits representative of Kryvyi Rih basin.

The problem of classifying drawing figures created when caved ore flows from drawpoints under overlying waste rocks is actual and one of the difficult in the caved ore drawing theory.

As a rule, the research findings to report up-to-date concern shapes and parameters of figures of drawing ore with various physical and mechanical properties of the ore and overlying rocks $[1-10]$.

However, muck loss formation in crests on the contact with the solidifying backfill massif of I stage stopes after complete caved ore drawing from II stage blocks is still understudied.

The authors conducted laboratory experiments to fill this gap. The experiments were conducted as follows.

The first set of experiments (I option) models conditions of caved ore drawing from a II stage block located on the contact with the solidifying massif of I stage stopes.

Here, the muck ore-solid massif contact surface is assumed vertical according to the classical technologies of stope mining.

The basic laboratory model is given in Fig. 3 .

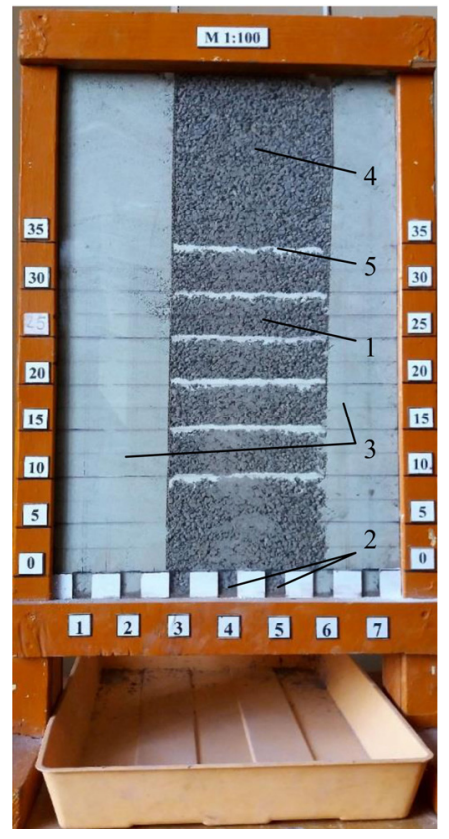

Fig. 3. The laboratory bench for drawing muck under overlying caved rocks on the contact with vertical side surfaces of the solidifying backfill of I stage stopes: 1 - II stage block muck, 2 - draw cones, 3 - the solidifying backfill massif of I stage stopes, 4 - waste rocks, 5 - the ore-rock contact line.

Fig. 4 presents the initial and final stages of muck drawing from a II stage block on the contact with vertical side surfaces of the solidifying backfill with muck loss formation in crests on the contact with the solidifying backfill massif.

The modeling technology consists in the following.

The model with the designed parameters is filled with the amount of ore according to the conditions of the experiment. 
Waste rocks are placed on above the ore.

Ore drawing is performed until its complete discharge from the block characterized by appearance of the white chalk line separating the ore from the overlying waste ores.

$a$

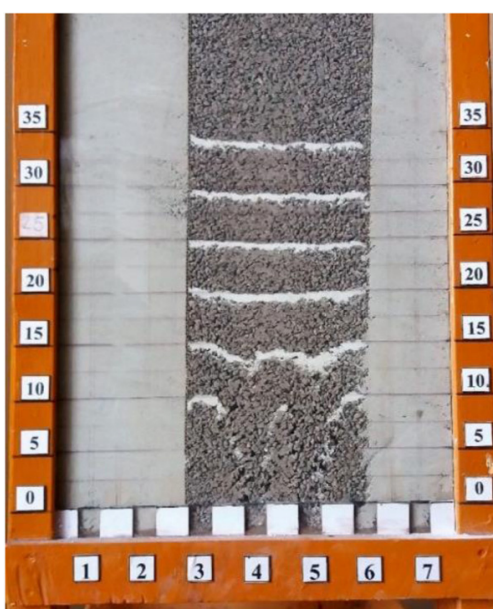

$b$

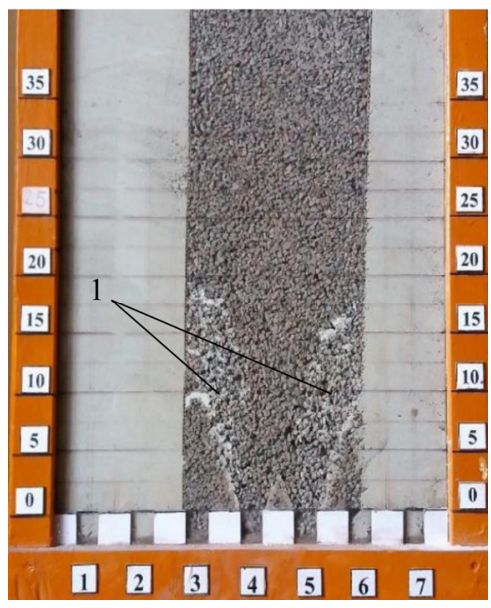

Fig. 4. The initial (a) and final (b) stages of muck drawing from a II stage block on the contact with vertical side surfaces of the solidifying backfill of I stage stopes: 1 - muck loss contours in crests.

The second set of experiments (II option) models conditions similar to those in the the previous set of tests with ore and wastes rocks.

Fig. 5 presents the laboratory bench for drawing muck under overlying caved rocks on the contour with inclined side surfaces of the solidifying backfill massif of I stage stopes.



Fig. 5. The laboratory bench for drawing muck under overlying caved waste rocks on the contact with inclined side surfaces of the solidifying backfill of I stage stopes: 1 - II stage block muck, 2 - draw cones, 3 - the solidifying backfill massif of I stage stopes, 4 - waste rocks, 5 - the ore-rock contact line; 6 - the inclined side surfaces of the ore-solidifying backfill contact. 
Unlike in the previous set of experiments, the second set provides for use of fragmented muck fraction and enclosing rocks, initial mining of I stage stopes with inclining the side surface of the lower part of the stope towards II stage blocks. The dip of the side surface of the lower part of the I stage stope equals to the generatix of the ellipsoid of drawing the muck from II stage blocks.

At the next stage the drawn ore is weighted, the ore remained in crests is weighted too. The obtained results are transformed into the drawn-lost ore percentage ratio.

Thus, the assumption that formation of the block sill with inclined side surfaces of the lower part of I stage stopes practically enables elimination of ore losses in crests on the contact with the solidifying backfill massif of I stage stopes after complete caved ore drawing from II stage blocks is confirmed.

Fig. 6 presents the initial and final stages of muck drawing from a II stage stope on the contact with inclined side surfaces of the solidifying backfill of I stage stopes and muck loss formation in crests on the contact with the solidifying backfill massif.

$a$

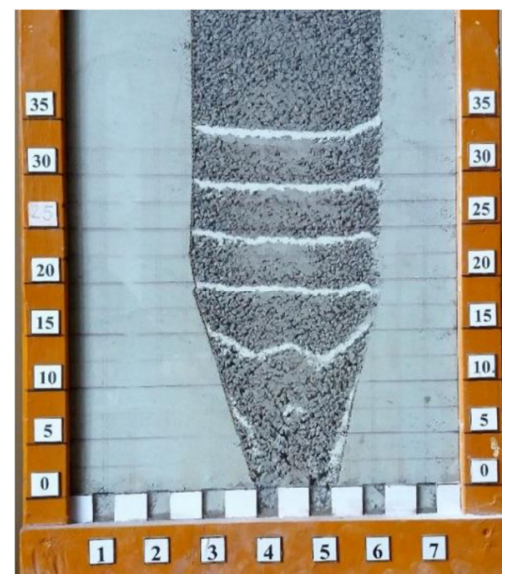

$b$

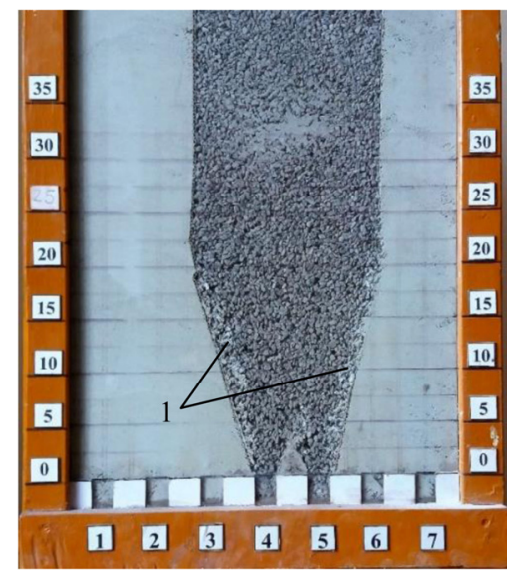

Fig. 6. The initial (a) and final (b) stages of muck drawing from a II stage block on the contact with inclined side surfaces of the solidifying backfill of I stage stopes: 1 - muck loss contours in crests.

\section{Results and discussion}

The investigations conducted result in the conclusion that ore losses in crests of dead II stage blocks on the contact with the backfill of I stage stopes depend on the dead stope height and the dip of the inclined side surfaces of the trapezoid basis of a sill pillar. The losses decrease to $0.7-1.2 \%$ if forming dips equal to the generatix of the draw cone which results in increase of extraction of ore from the block by $4.1-7.8 \%$.

Besides, in the course of experiments the following dependencies have been determined.

Absolute ore losses in crests on the boundary with the I stage sill stopes do not practically depend on block parameters. So, academician G.M. Malakhov's conclusions [1] on ore losses in crests between drawpoints being steady regardless the drawn ore layer height are confirmed.

At the same time, relative ore losses in crests depend on the height and width of a block, a number of drawpoints and a distance between them.

Ore layers in the model are separated by chalk strips located parallel to each other every $5 \mathrm{~cm}$ for better visualization of the muck ore drawing from the stope. Fig. 5 shows results 
of muck drawing at the initial and final stages with formation of ore losses on the contact with inclined side surfaces of the solidifying backfill of I stage stopes.

Analysis of the experiments data results in the following regularities.

The functional of the variable value of ore losses in crests depending on the dip of the side surface of the trapezoid sill on the boundary with the I stage sill stope massif with the differentiated block height is well approximated with the second-order polynomial curve.

For 25-meter-high stopes (panels) the value of ore losses in crests can be determined from the expression:

$$
L=0.031 \beta^{2}-4.473 \beta+163.42 ; R^{2}=0.9678,
$$

where $L$ is the value of ore losses in crests on the boundary with the I stage sill stope massif, $\% ; \beta$ is the dip of the side surface of the trapezoid sill on the boundary with the I stage sill stope massif, degrees; $R$ is validity of the approximation.

For 30-meter-high stopes (panels) the value of ore losses in crests can be determined from the expression:

$$
L=0.0269 \beta^{2}-3.8965 \beta+143.02, R^{2}=0.9692 .
$$

For 35-meter-high panels the value of ore losses in crests is determined from the expression:

$$
L=0.0233 \beta^{2}-3.3889 \beta+124.64, R^{2}=0.9695 .
$$

For 40-meter-high panels the value of ore losses in crests is determined from the expression:

$$
L=0.0201 \beta^{2}-2.9114 \beta+106.99, R^{2}=0.9734 .
$$

For 80-meter-high blocks the value of ore losses in crests can be determined from the expression:

$$
L=0.0101 \beta^{2}-1.4655 \beta+54.239, R^{2}=0.9663 .
$$

The generalized value of ore losses in crests depending on the dip of the side surface of the trapezoid sill on the boundary with the I stage sill stope massif with the differentiated block height is well approximated with the second-order polynomial curve and can be determined from the expression:

$$
L=\left(0.0258 \beta^{2}-3.7275 \beta+131.18\right) \cdot 1.5487 e^{-0,0099 h n}, R^{2}=0.9993
$$

where $h_{n}$ is the height of the dead panel, $\mathrm{m}$.

\section{Conclusions}

For the first time there have been determined numerical dependencies of ore losses in crests on the contact with the solidifying backfill massif of the I stage stopes after ore drawing from the II stage blocks on the dead stope height and dips of side surfaces of the trapezoid basis of sill pillars when forming the trapezoid sill of the block with inclined side surfaces of the lower part of the I stage stopes. It was experimentally proved that ore losses in crests on the contact with the backfill massif of the I stage stopes depend on the dead stope height and the dip of the inclined side surfaces of the trapezoid basis of a sill pillar. The losses decrease to $0.7-1.2 \%$ if forming dips equal to the generatix of the draw cone which results 
in increase of extraction of ore from the block by $4.1-7.8 \%$.

Considering the investigation findings and determined regularities of muck drawing on the contact with the solidifying backfill massif, the authors have developed a flowsheet of mining the area of the minefield with the trapezoid basis of blocks and combined backfill of the stope.

The proposed technology of forming the trapezoid block sill with inclined side surfaces of the lower part of I stage stopes enables elimination of ore losses in crests on the contacts with solidifying backfill massif of I stage stopes after complete caved ore drawing from II stage blocks.

The authors would like to express their sincere gratitude to the management of the PrJSC "Sukha Balka" for assistance in conducting the research and implementing its results.

\section{References}

1. Malakhov, G.M., Bezukh, V.P., \& Petrenko, P.D. (1968). Teoriya i praktika vypuska rudy. Moskva: Nedra.

2. Kulikov, V.V. (1980). Vypusk rudy. Moskva: Nedra.

3. Dubynin, N.G. (1965). Vypusk rudy pri podzevnoy razrabotke. Moskva: Nedra.

4. Guy Lauret et Patrice Brasse. (1999). Explortation selective des amas uraniferez: evolution de la methode d'exploitation. Mines carrierez - revue de la sosiete de l'industie minerale, (81), 41-44.

5. Kunin, I.K. (1964). Vypusk i dostavka rudy pri podzevnoy razrabotke. Moskva: Nedra.

6. Azarian, A.A., Kolosov, V.A., Morgun, A.V., Popov, C.O., \& Stupnik, N.I. (2012). Instruktsiya po normirovaniyu pokazateley izvlecheniya rudy po tekhnicheskim, tekhnologicheskim $i$ ekonomicheskim kriteriyam, ikh prognozirovaniyu $i$ uchetu $v$ protsesse podzemnoy razrabotki zhelezorudnykh mestorozhdeniy. Kryvyi Rih: Mira.

7. Kulikov, V.V., \& Deyneka, A.G. (1969). Metodika prognozirovaniya pokazateley izvlecheniya rudy. Moskva: Institut gornogo dela im. A.A. Skochinskogo.

8. Balkhavdarov, Kh.A., Sabatkoyev, M.M., \& Gabarayev, O.Z. (1991). Dinamika poter' rudy na dnishche mezhdu voronkami. Izvestiya Vuzov. Gornyy zhurnal, (10), 24-26.

9. Stupnik, M.I., Kalinichenko, V.O., Khivrenko, O.Ya., Kalinichenko, O.V., Hrishchenko, M.A., \& Teliapniov, V.O. (2016). Rozrobka ta doslidzhennia tekhnolohii vidpratsiuvannia zapasiv blokiv iz zastosuvanniam kombinovanoho vysokoefectyvnoho vypusku rudy. Visnyk Kryvorizkoho Natsionalnoho Universytetu, (43), 3-7.

10. Kalinichenko, O.V. (2017). Pidvyshchennia pokaznykiv vyluchennia zaliznykh rud pry vypusku obvalenoi rudnoi masy na kontakti z tverdiiuchym shtuchnym masyvom. Visnyk Kryvorizkoho Natsionalnoho Universytetu, (45), 118-122.

11. Stupnik, N., Kalinichenko, V., Kalinichenko, E., \& Pismennij, S. (2015). Features of underlying levels opening at "ArcelorMittal Krivyi Rih" underground mine. Theoretical and Practical Solutions of Mineral Resources Mining, 39-45. https://doi.org/10.1201/b19901-8 